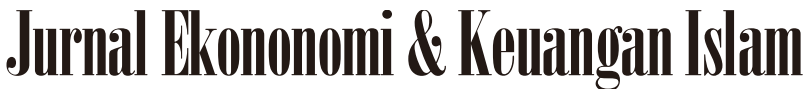

\author{
Available at http://journal.uii.ac.id/index.php/jeki
}

\section{Analisis perbandingan manajemen laba dengan metode Discretionary Accrual pada bank syariah dan bank konvensional}

Galuh Tri Pambekti

Fakultas Ekonomi, Universitas Wahid Hasyim

e-mail: galuh.seimek@gmail.com

\section{Keywords:}

Earnings management, Modified Jones Model, discretionary accrual, Conventional Bank and Islamic Bank

DOI:

$\underline{\text { 10.20885/JEKI.vol3.iss2.art4 }}$

\begin{abstract}
Earnings management is a deliberate act by managers using their power to determine the policy of regulating the level of corporate earnings. The purpose of this study is to prove that there is a difference between the level of earnings management in Islamic banks and conventional banks. The sample of this research are Islamic banks and conventional banks registered in Bank Indonesia for 2011-2015 The sample used is 96 samples. The testing technique in this study used independent mean test (Independent Sample T-Test). The earning management variables in this study were measured by discretionary accrual, measurement using Modified Jones Model (1991) to calculate total accruals. The results showed that the value of Sig. (2-tailed) is 0,000 indicates that there is a difference between Group A and Group B. It means that there is a difference between discretionary accrual ratio of conventional bank and discretionary accrual ratio of Islamic banks, it can be said there are differences in earnings management between Conventional Bank and Islamic Bank.
\end{abstract}

\section{Pendahuluan}

Sistem perbankan dan lembaga keuangan konvensional sudah berjalan sejak lama di Indonesia dan mengalami perkembangan yang pesat. Bank Konvensional adalah bank yang melaksanakan kegiatan usaha secara konvensional yang dalam kegiatannya memberikan jasa dalam lalu lintas pembayaran. Martono (2002) menjelaskan prinsip konvensional yang digunakan bank konvensional menggunakan dua metode, yaitu pertama, menetapkan bunga sebagai harga, baik untuk produk simpanan seperti tabungan, deposito berjangka, maupun produk pinjaman (kredit) yang diberikan berdasarkan tingkat bunga tertentu, kedua untuk jasa-jasa bank lainnya, pihak bank menggunakan atau menerapakan berbagai biaya dalam nominal atau prosentase tertentu. Sistem penetapan biaya ini disebut fee based.

Di sisi lain bank syariah baru dibentuk atas gagasan para pakar Islam yang dituangkan pada UndangUndang No 21 tahun 2008. Bank syariah adalah bank yang melaksanakan kegiatan usahanya berdasarkan prinsip bagi hasil atau syariah yang dalam kegiatannya memberikan jasa dalam lalu lintas pembayaran dan menekankan kesejahteraan investor. Prinsip syariah menurut pasal 1 ayat 13 Undang-Undang No 21 tahun 2008 tentang perbankan adalah aturan perjanjian bagi hasil yang berdasarkan hukum Islam antara bank dengan pihak lain untuk menyimpan dana atau pembiayaan kegiatan usaha dan kegiatan lainya yang bersifat pembiayaan syariah antara lain pembiayaan berdasarkan prinsip bagi hasil (mudharabah), pembiayaan berdasarkan prinsip penyertaan modal (musyarakah), prinsip jual beli barang dengan keuntungan (murabahah), pembiayaan barang modal berdasarkan prinsip sewa murni tanpa pilihan (ijarah), dan dengan adanya pilihan pemindahan kepemilikan atas barang yang disewa dari pihak bank oleh pihak lain (ijarah wa iqtina). Kesesuaian bank syariah dengan peraturan yang telah diterbitkan oleh pakar syariah menjadi salah satu faktor yang dipertimbangkan oleh nasabah dalam memilih 
investasi ke bank syariah, di samping itu mayoritas masyarakat Indonesia beragama Islam sehingga memberikan kesempatan berkompetisi dengan bank konvensional dalam hal menarik nasabah, bahkan dalam hal-hal khusus bank syariah menunjukka kinerja yang lebih baik dari bank konvensional.

Industri perbankan harus menyediakan laporan keuangan yang berkualitas dapat dipahami, relevan, materialitas, keandalan sebagai media untuk memberikan informasi mengenai posisi keuangan dan kinerja dari perusahaanya. Dalam penyusunan laporan keuangan, dasar akrual dipilih karena lebih rasional dan adil dalam mencerminkan kondisi keuangan perusahaan secara riil dalam Kieso, et al (2007). Namun di sisi lain penggunaan dasar akrual dapat memberikan keleluasaan kepada pihak manajemen dalam memilih metode akuntansi selama tidak menyimpang dari aturan standar akuntansi keuangan yang berlaku. Informasi akuntansi yang diperoleh melalui laporan keuangan merupakan salah satu informasi yang menjadi dasar utama bagi investor, kreditor maupun pemegang saham untuk menilai kinerja manajer dalam mengelola keuangan perusahaan.

Menurut Wahyudi \& Dwiyanto (2014), dasar penyusunan laporan keuangan ialah dasar akrual karena lebih rasional dan adil dalam mencerminkan kondisi keuangan perusahaan secara riil, namun kekuranganya ialah memberi fleksibilitas kepada pihak manajemen untuk memilih metode-metode akuntansi selama tidak menyimpang dengan standar akuntansi yang berlaku. Manajemen perusahaan termotivasi untuk memperlihatkan kinerja yang bagus dengan menghasilkan keuntungan maksimal bagi perusahaan dan stokeholder menginginkan laba yang tinggi sehingga manajemen cenderung memilih dan menerapkan metode akuntansi yang dapat memberikan informasi laba lebih baik. Apabila pihak manajemen tidak bisa memenuhi target laba yang ditentukan oleh dewan direksi, maka pihak manajemen akan memanfaatkan fleksibilitas yang diperbolehkan oleh standar akuntansi dalam menyusun laporan keuangan untuk memodifikasi laba perusahaan yang dilaporkan. Pihak manajemen dapat memodifikasi laba dengan menurunkan laba dikarenakan alasan tertentu. Tindakan manajemen untuk memodifikasi atau mempengaruhi tingkat laba dalam laporan keuangan disebut Earning Management.

Manajemen laba disengaja dan untuk tujuan tertentu, dalam batasan prinsip-prinsip akuntansi yang berterima umum (PABU/GAAP). Tujuan akhir adalah untuk memperoleh suatu nilai yang diharapkan terhadap laba yang dilaporkan pihak manajemen. Praktik manajemen laba bertujuan bagi kepentingan pribadi manager maupun perusahaan serta agar kinerja perusahaan yang dikelola terlihat baik. Dalam arti lain manajemen laba (earning management) adalah keputusan yang disengaja dimana manajer menggunakan kekuasaannya dalam menentukan kebijakan untuk mengatur tingkat laba perusahaan. Pengaturan ini harus sesuai dengan prinsip akuntansi yang berterima umum dan dapat diterima oleh prinsip-prinsip akuntansi dalam maupun luar negeri. Perlu diketahui bahwa manajemen laba yang dilakukan oleh manager dapat menjadi salah satu faktor kurangnya kredibilitas sebuah laporan keuangan. Ditambah lagi, manajemen laba akan menambah bias laporan keuangan dan dapat mengganggu bagi pengguna laporan keuangan yang mempercayai bahwa nilai yang disajikan adalah nila asli. (Pujiati \& Wahyuningsih, 2016).

Strategi untuk menaikan nilai perusahaan di mata investor cenderung meminimalkan kerugian yang mungkin dialaminya dalam menjalankan kegiatan usahanya. Upaya yang dilakukan pihak manajemen untuk menaikan nilai perusahaan dengan tujuan harga saham di bursa efek akan selalu naik dan setabil di pengaruhi oleh laba, resiko dan spekulasi. Oleh karena itu perusahaan yang nilai labanya selalu konsisten mengalami peningkatan di waktu tertentu biasanya akan mengalami penurunan yag lebih besar di bandingkan persentase peningkatan laba. Hal inilah yang membuat banyak pihak manajemen di berbagai perusahaan melakukan praktik manajemen laba sebagai salah satu upaya untuk mengurangi resiko harga sahamnya turun.

Menurut Nurianah (2015) manajemen laba adalah salah satu faktor yang mempengaruhi transparansi, kredibilitas laporan keuangan. Manajemen laba bisa menambah tidak konsisten pada laporan keuangan dan memberi informasi yang tidak bisa dijdikan dasar pertimbangan tentang kenerja perusahaan terhadap stokeholder (Hamdi, 2012). Sulistiawan et al (2011) menggunakan istilah earning management dengan sebutan creative accounting yang memiliki arti aktivitas badan usaha memanfaatkan teknik dan kebijakan akuntansi guna mendapatkan hasil yang diinginkan. Dapat disimpulkan bahwa manajemen laba adalah tindakan pihak manajemen dengan sengaja mempengaruhi nilai laba yang dilaporkan oleh perusahaan dengan cara menurunkan atau menaikan yang sesuai dengan prinsip-prinsip akuntansi yang berlaku, dengan tujuan mendapatkan hasil yang diinginkan oleh pihak manajemen. Menurut Scott (2003), ada beberapa bentuk manajemen laba yang ditemui di praktiknya diantaranya yaitu taking a bath, income minimization, incomemaximization dan income smoothing.

Pengkajian melalui penggunaan akrual dilakukan untuk mengetahui kemungkinan adanya manajemen laba dalam laporan keuangan. Secara teknis akrual adalah selisih antara kas dengan laba. Akrual yang disusun berdasarkan estimasi-estimasi tertentu merupakan faktor utama pembentuk laba. Beberapa cara yang dilakukan untuk mempengaruhi nilai laba perusahaan yang berkaitan dengan akrual adalah dengan menaikan atau menurunkan biaya amortisasi, biaya depresiasi, mencatat kewajiban yang besar atas biaya garansi, potongan harga serta mencatat persediaan yang sudah using. Apabila discretionary accrual suatu perusahaan cukup tinggi dibandingkan dengan rata-rata discretionary accrual pada umumnya, maka hal itu dapat digunakan sebagai indikasi terdapat manajemen laba pada perusahaan tersebut. Besarnya discretionary accrual juga dapat diketahui 
dengan cara membandingkan rata-rata discretionary accrual antara dua kelompok perusahaan, Jones (1991). Jika salah satu kelompok mempunyai discretionary accrual lebih tinggi dengan perbedaan yang signifikan, maka hal itu merupakan indikasi terdapat manajemen laba pada kelompok perusahaan tersebut.

Pelaporan berbasis akrual, bagi pengguna laporan keuangan dapat digunakan untuk mengukur akuntabilitas atas pemanfaatan sumber daya, kinerja, posisi keuangan dan arus kas dari entitas dan membuat keputusan dalam menjalankan bisnis. Menurut IFAC (2002), pelaporan berbasis akrual dapat digunakan untuk mengevaluasi kinerja. Wynne (2007) mengungkapkan manfaat penerapan basis akrual diantaranya, basis akrual mampu menghasilkan informasi keuangan yang lebih komprehensif. Manao (2006) membandingan penggunaan basis akrual dengan basis kas. Basis akrual dianggap lebih banyak digunakan pada sektor komersial karena memiliki kapasitas dalam menghasilkan penilaian multidimensi terhadap posisi keuangan. Jones \& Pendleburry (1988) mengemukakan basis akrual menggunakan konsep capital maintenance yang baik.

Padmantyo (2010) menyatakan bahwa manajemen laba dapat dibedakan menjadi baik dan buruk. Manajemen laba yang baik dilakukan untuk memberikan nilai bagi pemegang saham lewat keputusan-keputusan bisnis yang dapat diterima, sementara itu manajemen laba yang buruk dilakukan untuk menyembunyikan kinerja perusahaan yang sesungguhnya. Bank syariah sebagai bank berprinsip Islam tidak diperbolehkan melakukan praktik manajemen laba begitu juga dengan bank konvensional. Hal ini akan dapat memberikan informasi yang tidak tepat kepada pengguna laporan keuangan sebagai informasi kinerja suatu perusahaan. Menurut Fatwa Dewan Syariah Nasional No.15/DSN-MUI/IX/2000 tentang Distribusi Hasil Usaha, untuk kemaslahatan dalam pencatatan laporan keuangan disarankan penggunaan sistem basis akrual.

Sampai saat ini masih terdapat perbedaan pandangan dan pemahaman terhadap manajemen laba. Perbedaan pandangan ini secara umum terjadi antara praktisi dan akademisi yang pada dasarnya mempertanyakan apakah manajemen laba dapat di kategorikan sebagai kecurangan atau tidak. Para praktisi menilai manajemen laba sebagai kecurangan, sementara akademisi menilai manajemen laba tidak bisa dikategorikan sebagai kecurangan.

Karateristik bank syariah berbeda dengan sistem yang ada perbankan konvensional. Dalam undangundang no 21 tahun 2008 tentang perbankan syariah, bank syariah adalah perbankan yang dalam menjalankan kegiatan usahanya berdasarkan prinsip syariah (syari a compliance). Implikasinya, bank syariah tidak hanya diatur oleh undang-undang perbankan tetapi juga prinsip syariah dalam kegiatan bertransaksi. Selain itu, adanya kebijakan dual banking system di industri perbankan konvensional sesuai undang-undang No. 21 tahun 2008, dimana bank konvensional boleh membuka unit usaha syariah yang merupakan cikal bakal berdirinya bank umum syariah pada umumnya, sehingga dimungkinkan praktik manajemen laba dapat terjadi di bank syariah, karena dalam beberapa penelitian yang dilakukan di bank konvensional, terbukti bank tersebut melakukan praktik manajemen laba (Suryanto, 2014).

Praktik manajemen laba di bank syariah dan bank konvensional menarik untuk diketahui lebih lanjut. Bank syariah sebagai bank dengan prinsip-prinsip syariah yang bersumber pada Al Qur an dan Al Hadist tidak dibenarkanadanya rekayasa pada laporan keuangannya. Nurianah (2015) membandingkan manajemen laba yang dilakukan bank syariah dan bank konvensional. Hasil penelitian menyebutkan manajemen laba pada bank syariah lebih rendah dibandingkan dengan bank konvensional. Sejalan dengan penelitian Quttainah et al (2013), dimana bank syariah lebih sedikit melakukan manajemen laba jika dibandingkan dengan bank konvensional. Penelitian tersebut juga membahas faktor agama memiliki pengaruh pada manajer dalam mengambil kebijakan dan keputusannya serta adanya Dewan Pengawas Syariah yang mengawasi semua aktivitas operasional bank syariah terkait pemenuhan aspek etika dan hukum Islam. Bertolak belakang dengan penelitian Rahman (2012) dimana rata-rata manajemen laba pada bank syariah dan bank konvensional tidak terdapat perbedaan menurut ukuran-ukuran yang digunakan.

Penelitian Trisnawati \& Sasongko (2012) menemukan praktek manajemen laba pada perusahaan yang tergabung dalam indeks syariah dan indeks konvensional di Indonesia pada periode 2004-2010, dengan kecenderungan menaikkan angka laba. Dalam penelitian Nurianah (2015), bank syariah melakukan manajemen laba lebih rendah dibandingkan dengan bank konvensional. Selain itu status bank syariah memiliki hubungan negatif yang signifikan dengan manajemen laba. Hal ini menunjukkan bahwa bank syariah memiliki akrual discressionary lebih rendah dari bank non-Islam. Etika Islam juga memiliki peran dalam monitoring untuk mengurangi tindakan oportunistik manajerial dalam pengelolaan pendapatan melalui basis akrual. Berdasarkan teori-teori di atas dan adanya penelitian sebelumnya mengenai praktik manajemen laba pada bank syariah dan bank konvensional, maka menduga adanya perbedaan antara manajemen laba pada bank umum syariah dan bank konvensional.

\section{Metode Penelitian}

Sampel dalam penelitian ini adalah Bank Umum dan Bank Umum Syariah yang terdaftar di bank Indonesia periode 2011-2015. Teknik pengujian dalam penelitian ini menggunakan uji perbedaan rata-rata independen (independent sample t-test). Uji independent sample $T$-Test digunakan untuk mengetahui ada atau tidak perbedaan rata-rata, manakah yang lebih tinggi atau rendah antara dua kelompok sampel yang tidak ada hubungan dan biasanya data 
yang diolah atau digunakan bersifat interval atau rasio.Uji normalitas bertujuan untuk menguji apakah dalam model regresi, variabel penggangu atau residual memiliki distribusi normal, menggunakan uji statistic nonparametik Kolmogorof-Smirnov (K-S) dengan tingkat signifikann $\alpha=0,05$.

Variabel earning management dalam penelitian ini diukur dengan menggunakan discretionary accrual, pengukuran dilakukan menggunakanModified Jones Model (1991) untuk menghitung total akrual. Total Accruals pada periode $\mathrm{t}$ merupakan selisih antara laba operasi (operating income), yang dalam hal ini sama dengan pendapatan sebelum extraordinary items pada periode t, dan aliran kas dari aktivitas operasi (cash flow from operating activities) pada periode $t$. Adapun tahap-tahap menentukan nilai discretionary accrual sebagai berikut:

1) Menghitung total akrual

$$
T A C_{t}=N I_{t}-C F O_{t}
$$

Keterangan:

$\mathrm{TACt}=$ Total akrual perusahaan I pada tahun $\mathrm{t}$

$N I t=$ Laba operasi perusahaan I pada tahun $\mathrm{t}$

$C F O t=$ Kas dari operasi perusahaan I pada tahun $\mathrm{t}$

2) Dilakukan estimasi dengan menggunakan model

$$
\frac{T A_{i t}}{A_{i t-1}}=a_{1}\left(\frac{1}{A_{i t-1}}\right)+b_{1}\left(\frac{\Delta P O_{i t}}{A_{i t-1}}\right)+b_{2}\left(\frac{P P E_{i t}}{A_{i t-1}}\right)+\varepsilon_{i t}
$$

Keterangan:

$T A_{i t}=$ total akrual bank umum syariah/ bank konvensional $i$ pada bulan $\mathrm{t}$,

$A_{i t-1}=$ total aktiva bank umum syariah/bank konvensional $i$ pada bulan $\mathrm{t}-1$,

$\triangle P O_{i t}=$ selisih pendapatan operasi bank umum syariah/bank konvensional i pada bulan $\mathrm{t}$ dengan $\mathrm{t}-1$,

$P P E_{i t}=$ property, plant, and equipment (aktiva tetap) bank syariah/bankkonvensional i pada bulan t.

Nilai perkiraan error $\left(\varepsilon_{\mathrm{it}}\right)$ yang diperoleh dari persamaan regresi diatas merupakan nilai akrual diskresioner (discretionary accruals) yang digunakan sebagai mengukur tingkat manajemen laba pada bank syariah dan bank konvensional. Untuk menguji indikasi praktik manajemen laba di bank umum syariah digunakan uji beda, yaitu apakah rata-rata nilai $\mathrm{AD}$ pada bank syariah $\neq 0$.

\section{Hasil dan Pembahasan}

Jumlah sampel yang digunakan yaitu 96 sampel dengan rincian terdiri dari 20 Bank Konvensionaldan 12 Bank Umum Syariah, dengan time series 5 tahun. Data tersebut diperoleh berdasarkan kriteria sampel yang diambil dengan metode purposive sampling. Untuk menguji normalitas data dalam penelitian ini digunakan analisis Uji normalitas menggunakan uji Kolmogorov-Smirnov. Jika signifikansi di atas 0,05 maka tidak terdapat perbedaan yang signifikan antara data yang akan diuji dengan data normal baku, artinya data yang diuji normal. Berikut adalah hasil uji Kolmogorov-Smirnov:

\begin{tabular}{|c|c|c|}
\hline & & $\begin{array}{l}\text { Unstandardized } \\
\text { Residual }\end{array}$ \\
\hline $\mathrm{N}$ & & 96 \\
\hline \multirow[t]{2}{*}{ Normal Parameters ${ }^{\mathrm{a}, \mathrm{b}}$} & Mean & 0,0000054 \\
\hline & Std. Deviation & 73765689292,6662300 \\
\hline \multirow[t]{3}{*}{ Most Extreme Differences } & Absolute & 0,050 \\
\hline & Positive & 0,050 \\
\hline & Negative & $-0,045$ \\
\hline \multicolumn{2}{|l|}{ Test Statistic } &, 050 \\
\hline \multicolumn{2}{|c|}{$\begin{array}{l}\text { Asymp. Sig. (2-tailed) } \\
\text { a. Test distribution is Normal. } \\
\text { b. Calculated from data. }\end{array}$} & $200^{\mathrm{c}, \mathrm{d}}$ \\
\hline
\end{tabular}

Tabel 1: Hasil Uji One-Sample Kolmogorov-Smirnov 
Berdasarkan hasil uji diatas, dapat dilihat signifikasi sebesar 0,200. Signifikansi di atas 0,05 maka berarti tidak terdapat perbedaan yang signifikan antara data yang akan diuji dengan data normal baku berarti data yang diuji normal. Pada uji independent sample $T$-Test sampel dibagi menjadi dua kelompok. Kelompok A yaitu rasio discretionary accrual Bank Konvensional, sementara Kelompok B yaitu rasio discretionary accrual Bank Umum Syariah. Pembagian kelompok ini bertujuan untuk menunjukkan bahwa rasio discretionary accrual Bank Konvensional berbeda atau tidak berhubungan satu sama lain dengan rasio discretionary accrual Bank Umum Syariah. Pengujian menggunakan tingkat signifikansi $\alpha=5 \%$. Berikut adalah hasil uji independent sample $T-$ Test:

Tabel 2: Hasil Uji Independent Sample t-Test

\begin{tabular}{llrrrr}
\hline & Kelompok & N & Mean & Std. Deviation & Std. Error Mean \\
\hline \multirow{2}{*}{ Nilai } & Kelompok A & 84 & 15.3388 & 0.57234 & 0.06245 \\
& Kelompok B & 12 & 27.1850 & 0.49421 & 0.14267 \\
\hline
\end{tabular}

Sumber: data diolah

Nilai standar deviasi data pada Kelompok A sebesar 0,57234 lebih kecil dari nilai rata-rata sebesar 15,3388. Hal tersebut menunjukkan bahwa penyebaran data rasio discretionary accrual Bank Konvensional (Bank Umum) dalam penelitian ini merata dan tidak terdapat perbedaan yang tinggi antara data yang satu dengan data yang lainnya.Nilai standar deviasi data pada Kelompok B sebesar 0,49421 lebih kecil dari nilai rata-rata sebesar 27,1850. Hal tersebut menunjukkan bahwa penyebaran data rasio discretionary accrual Bank Umum Syariah (BUS) dalam penelitian ini merata dan tidak terdapat perbedaan yang tinggi antara data yang satu dengan data yang lainnya.

1) Uji Homogenitas data

Hasil uji Levene's Test for Equality of Variances digunakan untuk melihat perbedaan varian (homogenitas).

Kriteria pengujian adalah:

Sig. $\mathrm{p}<0,05=$ data tidak homogen

Sig. $\mathrm{p}>0,05=$ data homogen

Dari table diatas tampak bahwa $F=2,431$ dan Sig. $p=0,203$. Karena Sig. $p=0,203 p>0,05$, maka dapat dikatakan bahwa tidak ada perbedaan varian pada rasio discretionary accrual Bank Konvensional dan rasio discretionary accrual Bank Umum Syariah atau data equal/homogen.

2) Equal variances assumed

Jika data homogen, maka membaca lajur kiri Equal variances assumed. Sebaliknya jika data tidak homogen, maka membaca lajur kiri Equal variances not assumed. Karena data pada penelitian ini homogeny, maka interpretasi selanjutnya membaca lajur kiri dari Equal variances assumed. Dari table diatas terlihat bahwa nilai t hitung 0,0547 >0,05, artinya ada perbedaan rasio discretionary accrual Bank Konvensional dan rasio discretionary accrual Bank Umum Syariah.

3) Uji Perbedaan dengan Sig. (2-tailed)

Dasar kriteria pengujian sebagai berikut:

Jika probabilitas sig (2-tailed) $>0,05$, maka $\mathrm{H} 0$ diterima atau H1 ditolak

Jika probabilitas sig (2-tailed) $<0,05$, maka H1 diterima atau H0 ditolak

Dari hasiluji independent sample T-Test lajur kiri Equal variances assumed diatas, menunjukkan bahwa nilai Sig. (2-tailed) $0,000<0,05$. Sesuai dasar pengambilan keputusan dalam uji independent sample T-Test, dapat disimpulkan bahwa H0 ditolak, H1 diterima. Artinya bahwa terdapat perbedaan antara Kelompok A dan Kelompok B. Sehingga hasil penelitian ini menunjukkan bahwa terdapat perbedaan antara rasio discretionary accrual Bank Konvensional dan rasio discretionary accrual Bank Umum Syariah, atau dapat dikatakan terdapat perbedaan antara manajemen laba Bank Konvensional dan manajemen laba Bank Umum Syariah.

Total akrual yang merupakan selisih antara laba dan arus kas yang berasal dari aktivitas operasi, memisahkan total akrual menjadi dua yaitu akrual kebijakan (discretionary accrual) dan akrual bukan kebijakan (nondiscretionary accrual) sebagai alat untuk mengetahui apakah terjadi praktik manajemen laba. Total akrual digunakan untuk menentukan manajemen laba pada tahap awal, selanjutnya mengkhususkanya pada discretionary accrual sebagai ukuran manajemen laba. Discretionary accrual merupakan kebijakan akuntansi yang memberikan ruang kebebasan terhadap pihak manajemen dalam mengukur jumlah transaksi akrual secara fleksibel. Kebijakan akuntansi akrual adalah suatu cara untuk mempengaruhi pelaporan laba yang sulit dideteksi melalui metodemetode akuntansi yang berkaitan dengan akrual. Bisa disimpulkan bahwa discretionary accrual merupakan transaksi atau metode akuntansi yang besarnya dipengaruhi oleh kebijakan manajemen. 
Penelitian ini merupakan hasil pengembangan penelitian terdahulu yang telah dilakukan oleh beberapa penulis, yakni tentang praktik manajemen laba di sektor perbankan Indonesia. Hasil penelitian ini menunjukkan bahwa terdapat perbedaan antara rasio discretionary accrual Bank Konvensional (Bank Umum) dan rasio discretionary accrual Bank Umum Syariah (BUS), atau dapat dikatakan terdapat perbedaan antara manajemen laba Bank Konvensional (Bank Umum) dan manajemen laba Bank Umum Syariah (BUS). Hasil penelitian ini menjawab hipotesis H1: Terdapat perbedaan antara manajemen laba pada bank umum syariah dan bank konvensional, diterima.

Hasil penelitian ini memberikan bukti empiris bahwa metode akrual dapat dijadikan instrument untuk mengetahui ada atau tidaknya perbedaan manajemen laba antara Bank Konvensional dan Bank Umum Syariah. Bank syariah dan bank konvensional dalam beberapa hal memiliki persamaan, terutama dalam sisi teknis penerimaan uang, mekanisme transfer, teknologi computer yang digunakan, persyaratan umum pembiayaan dan syarat-syarat umum pembiayaan, laporan keuangan dan sebagainya. Perbedaan antara bank syariah dan bank konvensional menyangkut aspek legal, struktur organisasi, bisnis usaha yang dibiayai dan lingkungan kerja. Metode akrual yang digunakan dalam penelitian ini dapat memberikan informasi mengenai kebutuhan biaya untuk produksi. Manfaat basis akrual ialah mampu menunjukkan hasil kinerja manajemen yang tidak dipengaruhi oleh waktu pengeluaran dan penerimaan kas, melainkan lebih ke arah kondisi organisasi sebenarnya yang ditunjukkan oleh akun-akun yang ada di neraca. Sehingga basis akrual dapat pula mengidentifikasi perubahan posisi keuangan, peluang dari pemanfaatan sumber daya di masa depan guna mencapai pengelolaan sumber daya yang sukses, dan bagaimana perusahaan membiayai aktivitasnya untuk memenuhi kebutuhan kasnya. Basis akrual dapat memfasilitasi perusahaan untuk mengukur kapasitas yang dimilikinya.

Hasil penelitian terdahulu yang sama dengan hasil penelitian ini adalah penelitian Quttainah et al (2013), hasilnya konsisten dengan hasil penelitian dari Nurianah (2015) yang menyatakan bahwa manajemen laba pada bank syariah lebih rendah dari bank konvensional, sehingga diantara keduanya terdapat berbedaan. Hasil penelitian lain yang serupaoleh Pujiati \& Wahyuningsih (2016), terdapat perbedaan manajemen laba bank konvensional dan bank syariah. Terbukti Manajemen laba Bank Konvensional lebih tinggi dari Bank Syariah.

Rendahnya manajemen laba di bank Syariah juga dipengaruhi oleh keberadaan Dewan Pengawas Syariah (DPS). Keberadaan Dewan Pengawas Syariah (DPS) dianggap mampu mengurangi tindakan manajemen laba di bank syariah (Suryanto, 2014). Tugas pengawasan terhadap kegiatan operasional bank syariah yang dilakukan oleh DPS terbukti dapat dilaksanakan dengan baik. Hasil penelitian ini sesuai dengan penelitian yang dilakukan oleh Ghayad (2008), Anwar (2011), Setiawati (2010) yang mengungkapkan bahwa Dewan Pengawas Syariah (DPS) yang telah berfungsi dengan baik mampu mengurangi praktik manajemen laba di bank syariah.

Analisis pada manajemen awalnya dilakukan oleh Scott (2003) mengenai bagaimana pola manajemen laba dilakukan diantaranya, pertama, taking a bath, dimana pola ini terjadi pada saat penggantian anggota organisasi, termasuk pada saat pengangkatan Chief Executive Officer (CEO) baru dengan memberikan laporan bahwa terdapat saldo rugi dalam jumlah yang besar. Harapan dari tindakan ini adalah agar terjadi peningkatan laba pada periode yang akan datang. Kedua income minimization, dengan mengurangi jumlah laba yang akan dilaporkan. Tindakan ini dilakukan ketika perusahaan mendapat tikngkat keuntungan tinggi, tujuannya adalah agar secara politis perusahaan mendapatkan perhatian. Ketiga income maximization, yaitu memaksimumkan keuntungan yang dilaporkan dengan tujuan untuk mendapat bonus yang lebih besar. Langkah ini dilakukan pada saat terjadi penurunan laba. Kecenderungan manajer untuk memaksimalkan laba juga dapat dilakukan pada perusahaan yang melakukan suatu pelanggaran perjanjian utang. Dan keempat income smoothing, perusahaan melakukan perataan laba yang dilaporkan, tujuannya untuk dapat mengurangi naik turunnya laba yang terlalu besar. Hal ini dilakukan karena investor umumnya lebih menyukai laba yang relatif stabil.

Pola manajemen laba tersebut bertentangan dengan kaidah Islam. Penjelasan Al-Qur'an dan Hadis mengenai manajemen laba yaitu terkait larangan mengambil keuntungan dengan jalan yang dibenci agama Islam, diantaranya Surat An-Nisa ayat 29, Artinya: "Wahai orang-orang yang beriman, janganlah kalian memakan harta-harta kalian di antara kalian dengan cara yang batil, kecuali dengan perdagangan yang kalian saling ridha. Dan janganlah kalian membunuh diri-diri kalian, sesungguhnya Allah itu Maha Kasih Sayang kepada kalian”.

Dalam ayat tersebut dijelaskan mengenai hokum transaksi secara umum, lebih khusus kepada transaksi perdagangan, bisnis jual beli, dan transaksi muamalah yang berhubungan dengan harta, seperti harta anak yatim, mahar, dan sebagainya. Dalam ayat ini Allah mengharamkan orang yang beriman untuk memakan, memanfaatkan, menggunakan, (dan segala bentuk transaksi lainnya) harta orang lain dengan jalan yang batil, yaitu yang tidak dibenarkan oleh syari'at. Boleh melakukan transaksi terhadap harta orang lain dengan jalan perdagangan dengan asas. Dan dalam ayat ini Allah juga melarang untuk bunuh diri, baik membunuh diri sendiri maupun saling membunuh. Dan Allah menerangkan semua ini, sebagai wujud dari kasih sayang-Nya, karena Allah itu Maha Pengasih, salingridha, salingikhlas.

Perlakuan manajemen laba dengan Taking a bath, Income minimization, Income maximization, Income smoothing tidaklah sesuai dengan syariat Islam. Dalam surat An Nisa ayat 29, diterangkan bahwa transaksi bisnis 
tidak boleh dilakukan dengan jalan yang bathil dan adanya keridhoan dalam melakukan transaksi. Berbeda dengan praktek manajemen laba, manajer keuangan melaporkan keuangan yang telah di ubah sedemikian rupa agar mendapatkan keuntungan. Misalnya dengan menurunkan jumlah laba yang akan dilaporkan padahal perusahaan memperoleh tingkat profitabilitas yang tinggi dengan maksud untuk memperoleh perhatian secara politis. Hal tersebut tidaklah diperbolehkan karena tidak mengandung unsure kejujuran didalamnya.Walaupun prkatek manajemen laba diatur dalam Prinsip-prinsip Akuntansi yang Berterima Umum (PABU/GAAP) (Arisandy, 2015).

Teori lain yang memperkuat manajemen laba bank Syariah lebih rendah dibandingkan bank Konvensional yaitu model Islam dalam menghadapi manajemen laba yang dikemukakan oleh Hossain et al (2014). Konsep Islam dapat dikaitkan dalam menghadapi masalah manajemen laba. Konsep Fitrah secara alami menyoroti manusia untuk kecenderungan menuju kebaikan. Padahal manusia cenderung bisa rusak oleh lingkungan dan kehendak bebasnya. Itulah sebabnya, memelihara dan merawat Fitrah dibutuhkan. Ajaran Akhlaq dapat memastikan hal tersebut. Akhlaq bisa memastikan bahwa manusia bisa membedakan antara baik dan buruk dan dengan demikian manusia dapat berperilaku etis. Etis yang dimaksud yaitu berorientasi untuk menciptakan niat baik (Niyyah) pada manusia. Dengan demikian, seseorang akan menerapkan upaya tertinggi (Ijtihad) dalam mengambil keputusan demi kepentingan umum (Maslahah). Model digambarkan melalui gambar 1 dibawah.

Gambar 1 menunjukkan bahwa pendidikan dan pelatihan Akhlaq dapat mempertahankan Fitrah manusia dan dengan demikian niat manusia menjadi murni dan baik. Pendidikan dan pelatihan Akhlaq dapat dianggap penting untuk memastikan perilaku etis. Pelatihan Akhlaq bisa jadi dilakukan di tingkat keluarga. Selain itu, lembaga pendidikan dan organisasi juga harus cukup mementingkan hal ini. Konsep semacam ini sangat mungkin diimplementasikan di bank Syariah.

Konsep yang dikemukakan oleh Hossain et al (2014) tersebut mendukung struktur Lembaga keuangan Syariah, khususnya Bank Syariah. Filosofi dasar operasional bank syariah dalam seluruh kegiatan transaksinya mencakup efesiensi, keadilan, dan kebersamaan. Efisiensi yaitu menerapkan prinsip tolong-menolong (ta'awun) yang tersinergu untuk mendapatkan kuntungan yang maksimal. Keadilan berarti bahwa tidak ada kecurangan dalam transaksi dan kerjasama, ikhlas, dengan akad yang jeas mengenai bagian input dna outputnya. Kebersamaan yaitu saling menawarkan pertolongan serta nasihat agar dapat meningkatkan produktivitas. Berikut ini prinsipprinsip yang berlaku pada bank syariah. Dalam rangka menjalankan kegiatannya, bank syariah harus berlandaskan pada Alquran dan hadis. Bank syariah mengharamkan penggunaan harga produknya dengan bunga tertentu. Bagi bank syariah, bunga bank adalah riba.

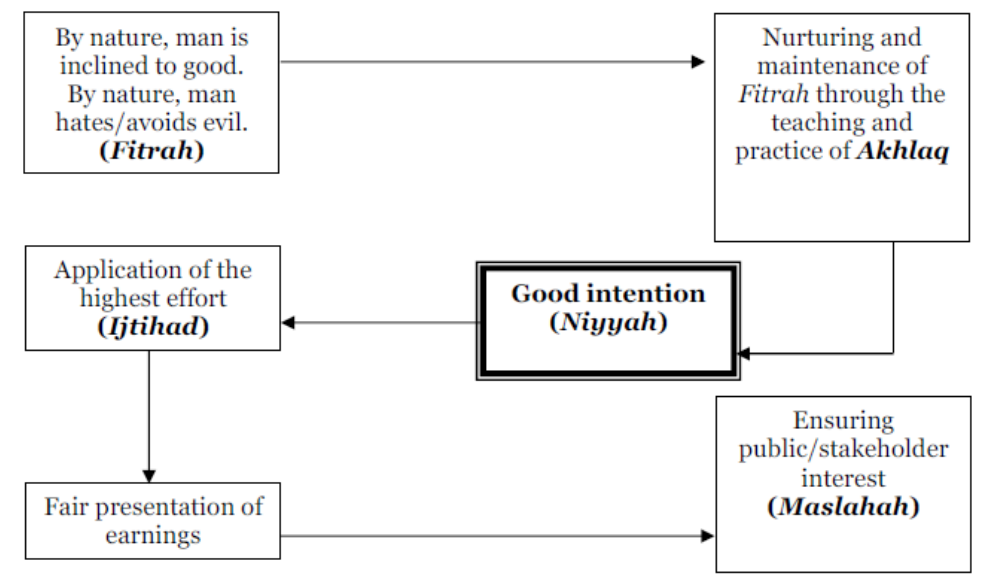

Sumber: Hossain et al (2014)

Gambar 1: Konsep Islam dalam Manajemen Laba

Jauh sebelum Islam melarang praktik riba, Taurat dan Injil telah melarang riba. Penyimpangan praktik terjadi di sana-sini, sehingga praktik riba merupakan kelaziman bahkan juga di pusat Islam, Makkah dan Madinah. Sejarah membuktikan praktik ini dikikis habis di zaman Rasulullah SAW dan Khulafaur Rasyidin. Muawiyah bin Abu Sufyan (661 M) mengawali pemerintahan Bani Umayyah sampai khalifah terakhirnya Marwan bin Muhammad (750 M). Ketika itu mulai dikenal praktik penukaran uang, penitipan uang, peminjaman uang, pengiriman uang oleh jihbiz (suatu istilah yang berasal dari bahasa Persia untuk petugas pajak tanah). Profesi jihbiz semakin berkembang di zaman Bani Abbasiyah yang diawali oleh Abul Abbas al Saffah (750 M) dan diakhiri oleh al Muqtadir Billah (932 M).Hukum islam telah melarang riba seperti yang tercantum dalam Al- Qur an surat Al Baqarah ayat 275 ayat 130, atinya: "Orang-orang yang makan (mengambil) riba tidak dapat berdiri melainkan seperti berdirinya orang yang kemasukan syaitan lantaran (tekanan) penyakit gila. Keadaan mereka 
yang demikian itu, adalah disebabkan mereka berkata (berpendapat), sesungguhnya jual beli itu sama dengan riba, padahal Allah telah menghalalkan jual beli dan mengharamkan riba. Orang-orang yang telah sampai kepadanya larangan dari Tuhannya, lalu terus berhenti (dari mengambil riba), maka baginya apa yang telah diambilnya dahulu (sebelum datang larangan); dan urusannya (terserah) kepada Allah. Orang yang kembali (mengambil riba), maka orang itu adalah penghuni-penghuni neraka; mereka kekal di dalamnya."

Pengertian riba menurut Wibowo (2005), riba pada masa turunya Alquran adalah kelebihan yang dipungut bersama hutang yang mengandung unsure penganiayaan dan penindasan, bukan sekedar kelebihan atau penambahan dari jumlah hutang. Bank syariah ada dewan pengawas syariah yang mengatur atau mengawasi semua kegiatan oprasionalnya. Berdasarkan Undang-Undang No.10 Tahun 1998 tentang perubahan atas UU No 7 tahun 1992 tentang bank berprinsip syariah terdiri dari dewan komisaris dan direksi, disamping itu bank harus memiliki Dewan Pengawas Syariah (DPS) yang berkedudukan dikantor pusat bank. DPS adalah dewan yang bersifat independen yang dibentuk oleh Dewan Syariah Nasional.

Adapun peran Dewan Pengawas Syariah dalam perbankan yaitu mengawasi jalanya operasional bank sehari-hari agar selalu sesuai dengan ketentuan-ketentuan syariah karena tranksaksi-transaksi yang terjadi pada bank syariah sangat khusus, membuat pernyataan secara berkala (biasanya tiap tahun) bahwa yang diawasinya telah berjalan sesuai ketentuan syariah, serta meneliti dan membuat rekomendasi produk baru dari bank yang diawasinya.

\section{Kesimpulan}

Dari hasil uji independent sample T-Test diatas menunjukkan bahwa nilai Sig. (2-tailed) menunjukkan nilai 0,000 $<0,05$. Sesuai dasar pengambilan keputusan dalam uji independent sample $T$-Test, dapat disimpulkan bahwa $\mathrm{H} 0$ ditolak H1 diterima, yang artinya bahwa terdapat perbedaan antara Kelompok A dan Kelompok B. Sehingga hasil penelitian ini menunjukkan bahwa terdapat perbedaan antara rasio discretionary accrual Bank Konvensional dan rasio discretionary accrual Bank Umum Syariah, atau dapat dikatakan terdapat perbedaan antara manajemen laba Bank Konvensional dan manajemen laba Bank Umum Syariah.

Hasil pengujian ini menunjukan bahwa bank syariah memiliki manajemen laba yang lebih rendah dari bank konvensional. Hasil penelitian ini mendukung penelitian Nurianah (2015). Penelitian tersebut dilakukan untuk mengetahui tingkat manajemen laba antara perbankan syariah dan perbankan konvensional. Apakah manajemen laba pada perbankan syariah lebih rendah dari perbankan konvensional. Penelitian ini menggunakan variabel dummy untuk menentukan status syariah pada perbankan. Hasil penelitian menunjukan bahwa status syariah perbankan yang diwakili oleh variabel dummy berpengaruh terhadap manajemen laba.

Penelitian ini memiliki kekurangan yaitu dalam penggunaan metode pengukuran laba. Sangat banyak sekali metode pengukuran manajemen laba, misalnya Model Sloan (1996), Model Healy (1999), Model De Angelo (1986), Industry adjusted model menurut Dechow dan Sloan (1991), Model Beaver dan Engel (1996) tentang akrual khusus danlainnya. Diharapkan penelitian selanjutnya dapat menguji perbedaan manajemen laba Bank Konvensional dan Bank Umum Syariah menggunakan metode pengukuran yang lebih bervariatif.

\section{Daftar Pustaka}

Arisandy, Y. (2015). Manajemen laba dalam perspektif islam. MIZANI, 25 (2), 125-143

Hamdi, F. M., \& Zarai, M. A. (2013). Perspectives of earnings management in Islamic banking institutions. International Journal of Business and Management Invention, 2(9), 26-38.

Hossain, D., Karim, A., Kamarul, M., \& Houssem Eddine, C. (2014). Earnings Management and Islam. Labuan e-Journal of Muamalat and Society, (8) 2014, 87-97.

Jones, J. J. (1991). Earnings management during import relief investigations. Journal Of Accounting Research, 29 (2), $193-228$.

Jones, R. H., \& Pendlebury, M. (1988). Governmental Accounting, Auditing and Financial Reporting in the United Kingdom. Chan JL; Jones RH (1988) (eds) Governmental Accounting and Auditing: International Comparisons, London: Routledge, 52-81.

Kieso, D. E., Weygandt, J. J., \& Terry D. W. (2008). Akuntansi Intermediate. Edisi Keduabelas. Jakarta: Erlangga.

Manao, H. (2006). Goverment accounting developments: the Indonesian experience. Presented at the $10^{\text {th }}$ World Congress of Accounting Educators Istanbul, Turkey

Martono. (2002). Bank dan Lembaga Keuangan Lain. Yogyakarta: Ekonisia 
Nurianah. 2015. Apakah Manajemen Laba Pada Bank Syariah Lebih Rendah Dari Bank Konvensional?. Tesis tidak dipublikasikan, Universitas Sebelas Maret, Surakarta

Padmantyo, S. (2010). Analisis Manajemen Laba pada Laporan Keuangan Perbankan Syariah. Jurnal Manajemen dan Bisnis, 14 (2), 52-65.

Pujiati, L., \& Wahyuningsih, I. (2016). Perbedaan manajemen laba pada bank syariah dan bank konvensional yang terdaftar di otoritas jasa keuangan. Jurnal Akademika, 14(2), 113-118.

Quttainah, M. A., Song, L., \& Wu, Q. (2013). Do Islamic banks employ less earnings management?. Journal of International Financial Management \& Accounting, 24(3), 203-233.

Scott, W. R. (2003). Financial Accounting Theory. New Jersey: Prentice Hall Inc.

Sulistiawan, D., Y. Januarsi, \& L. Alvia. (2011). Creative Accounting: Mengungkap Manajemen Laba dan Skandal Akuntansi. Jakarta: Salemba Empat.

Trisnawati, R \& Sasongko N. (2012). Pengukuran manajemen laba : pendidikan terintegrasi. SNA IV.

Wahyudi, T., \& Dwiyanto, B. S. (2014). Pengaruh Manajemen Laba terhadap Peringkat Obligasi pada Saat Emisi. Jurnal Maksipreneur: Manajemen, Koperasi, dan Entrepreneurship, 3(2), 34-57.

Wibowo, E. (2005). Mengapa Memilih Bank Syari'ah. Bogor: Ghalia Indonesia.

Wynne, A. (2007). Is the move to accrual based accounting a real priority for public sector accounting. Public Fund Digest, 6(1), 25-39. 